\title{
Inhalation errors due to device switch in patients with chronic obstructive pulmonary disease and asthma: critical health and economic issues
}

This article was published in the following Dove Press journal:

International Journal of COPD

21 March 2016

Number of times this article has been viewed

\author{
Alessandro Roggeri ${ }^{1}$ \\ Claudio Micheletto ${ }^{2}$ \\ Daniela Paola Roggeri' \\ 'ProCure Solutions, Nembro, \\ Bergamo, Italy, ${ }^{2}$ Respiratory Unit, \\ Mater Salutis Hospital, Legnago, \\ Verona, Italy
}

\begin{abstract}
Background: Different inhalation devices are characterized by different techniques of use. The untrained switching of device in chronic obstructive pulmonary disease (COPD) and asthma patients may be associated with inadequate inhalation technique and, consequently, could lead to a reduction in adherence to treatment and limit control of the disease. The aim of this analysis was to estimate the potential economic impact related to errors in inhalation in patients switching device without adequate training.
\end{abstract}

Methods: An Italian real-practice study conducted in patients affected by COPD and asthma has shown an increase in health care resource consumption associated with misuse of inhalers. Particularly, significantly higher rates of hospitalizations, emergency room visits (ER), and pharmacological treatments (steroids and antimicrobials) were observed. In this analysis, those differences in resource consumption were monetized considering the Italian National Health Service (INHS) perspective.

Results: Comparing a hypothetical cohort of 100 COPD patients with at least a critical error in inhalation vs 100 COPD patients without errors in inhalation, a yearly excess of 11.5 hospitalizations, 13 ER visits, 19.5 antimicrobial courses, and 47 corticosteroid courses for the first population were revealed. In the same way, considering 100 asthma patients with at least a critical error in inhalation vs 100 asthma patients without errors in inhalation, the first population is associated with a yearly excess of 19 hospitalizations, 26.5 ER visits, 4.5 antimicrobial courses, and 21.5 corticosteroid courses. These differences in resource consumption could be associated with an increase in health care expenditure for INHS, due to inhalation errors, of $€ 23,444 / \mathrm{yr}$ in COPD and $€ 44,104 /$ yr in asthma for the considered cohorts of 100 patients.

Conclusion: This evaluation highlights that misuse of inhaler devices, due to inadequate training or nonconsented switch of inhaled medications, is associated with a decrease in disease control and an increase in health care resource consumption and costs.

Keywords: inhalers, devices, switch, training, errors, costs, asthma, COPD

\section{Introduction}

Asthma and chronic obstructive pulmonary disease (COPD) have relevant and increasing epidemiological and economic impact worldwide, ${ }^{1-4}$ with costs increasing with the worsening of the pathologies., 5

As a relevant proportion of patients affected by asthma and COPD are treated with inhaled drugs, ${ }^{7}$ an appropriate inhaler technique is necessary to obtain and maintain an effective management of these pathologies. As stated by the Guide For Asthma Management and Prevention (updated in 2015), ${ }^{8}$ up to $80 \%$ of asthma patients do not use their inhaler adequately, and this could lead to poorer symptom control and to a
Correspondence: Alessandro Rogger 24027, Nembro, Bergamo, Italy

$\mathrm{Tel}+3903552$ I 12 |

Email alessandro.roggeri@

procuresolutions.it (c) (1) (5) 2016 Roggeri et al. This work is published and licensed by Dove Medical Press Limited. The full terms of this license are available at https://www.dovepress.com/terms.php cC) and incorporate the Creative Commons Attribution - Non Commercial (unported, v3.0) License (http://creativecommons.org/licenses/by-nc/3.0/). By accessing the work you hereby accept the Terms. Non-commercial uses of the work are permitted without any further permission from Dove Medical Press Limited, provided the work is properly attributed. For permission for commercial use of this work, please see paragraphs 4.2 and 5 of our Terms (https://www.dovepress.com/terms.php). 
higher level of exacerbations. The importance of the choice of inhaler in the treatment of COPD patients is also underlined by the 2015 Global Initiative for Chronic Obstructive Lung Disease (GOLD) guidelines that point out the importance of effective drug delivery and training in inhaler techniques. ${ }^{9}$

The importance of inhaler devices for the effectiveness of inhaled drugs in the treatment of asthma and COPD is also recognized and underlined by the European Medicines Agency (EMA), which only considers approving the generic version of inhaler products if in vitro studies lead to a full therapeutic interchangeability; otherwise, lung deposition test and eventually, pharmacodynamics or even clinical studies might be required. EMA clearly stated that orally inhaled products have to be considered not as "generics" but as "hybrids". ${ }^{10}$

A recent Italian consensus document of the Italian Society of Allergy, Asthma and Clinical Immunology and the Italian Society of Respiratory Medicine recommend that patients who are familiar and stabilized with one inhaler should not be switched to a different one without their involvement and proper training. Inappropriate inhaler use and a low adherence to inhaled treatments could lead to poorer asthma and COPD control, and switching devices without suitable training could worsen these problems. ${ }^{11}$

Because different inhalation devices require very different techniques of use, the switch of device without training in COPD and asthma patients may be associated with a poor inhalation technique with critical errors and, consequently, in a reduction of adherence and worsening in disease control. An Italian study ${ }^{12}$ investigated the prevalence of inhalation errors and related health care resource consumption in a large population of patients with COPD and asthma.

The aim of this analysis was to estimate the possible economic impact on the Italian National Health Service (INHS) due to errors in inhalation in patients switching device without adequate training.

\section{Materials and methods}

An Italian observational, multicenter, cross-sectional study (The GENEBI Project [AIPO, Gruppo Educazionale for NEBulizers and Inhalers]) performed in 2008 conducted by Melani et $\mathrm{al}^{12}$ investigated the prevalence of inhaler misuse and health care resource consumption in a large population of adult patients experienced in the use of inhalers which referred to chest clinics throughout Italy. A total of 1,664 patients (adolescents and adult outpatients) being treated at 24 chest clinics around Italy were enrolled, most of whom were affected by asthma ( $42 \%$, mean age 51 years) and COPD (52\%, mean age 70 years). All patients attended the clinics and used inhalers regularly. Mean forced expiratory volume in 1 second was $60 \pm 20$ in COPD patients and $80 \pm 23$ in asthma patients. Regarding inhaler education in the selected population, one-third of patients had no education, another one-third received verbal instructions, and the latter one-third received practical demonstration of inhaler use. A detailed checklist of the inhalation technique errors is reported in the paper of Melani et al. ${ }^{12}$ The results of this study highlight higher health care resource consumption in patients experiencing critical inhaler errors vs patients without critical errors. Particularly, significantly higher rates of hospitalizations $(P=0.001)$, emergency room $(\mathrm{ER})$ visits $(P<0.001)$, and pharmacological treatments (steroids and antimicrobials, $P<0.001$ ) were observed for both pathologies (Table 1). The reported differences in resource consumption remain significant even after considering asthma and COPD separately.

For the aim of the present analysis, these differences in resource consumption were monetized from the INHS perspective by multiplying the differences in average resource consumption for their unitary cost in charge to INHS. National diagnosis related groups (DRGs) tariffs were considered for hospitalizations ${ }^{13}$ and ER visits, ${ }^{14}$ and the public price for drug consumption (average prices of the most widely used drugs were used to estimate the cost per course of treatment). Unitary costs considered for the base case analysis are shown in Table 2.

In order to test the results, a sensitivity analysis was performed considering Italian real-world data for COPD and asthma hospitalizations; particularly, for COPD, a cost of $€ 3,985 /$ hospitalization $^{5}$ was considered while, for asthma, a cost of $€ 2,640.75 /$ hospitalization (adapted from Dal Negro et $\mathrm{al}^{15}$ ) was considered. As highlighted by the unitary costs of hospitalizations derived from real-world evidences, particularly for some pathologies (ie, COPD), hospitalization-related costs could be higher than the standard DRGs tariffs and could represent valid data to perform a scenario analysis. This study was an economic evaluation based on another study (Melani et $\mathrm{al}^{12}$ ), therefore ethical approval and patients consent were not requested.

\section{Results}

Comparing a population of 100 COPD patients with at least a critical error in inhalation with 100 COPD patients without errors in inhalation, the first population was associated with an excess of 11.5 hospitalizations, 13 ER visits, 19.5 antimicrobial courses, and 47 corticosteroids courses. In the same way, when 100 asthma patients with at least a critical error in inhalation, were compared with 100 asthma patients without errors in inhalation, the first population was associated with 
Table I Resource consumption associated with inhalation errors

\begin{tabular}{|c|c|c|c|c|c|c|c|c|}
\hline & \multicolumn{4}{|c|}{ COPD $(n=864)$} & \multicolumn{4}{|c|}{ Asthma $(n=703)$} \\
\hline & \multicolumn{2}{|c|}{$\begin{array}{l}\text { At least } \\
\text { a critical } \\
\text { inhaler } \\
\text { error* }\end{array}$} & \multirow{2}{*}{$\begin{array}{l}\text { \% difference } \\
\text { in health care } \\
\text { resource use } \\
\text { due to critical } \\
\text { inhaler errors }\end{array}$} & \multirow{2}{*}{$\begin{array}{l}\text { Absolute } \\
\text { difference in } \\
\text { health care } \\
\text { resource } \\
\text { use/ } 100 \text { patients }\end{array}$} & \multicolumn{2}{|c|}{$\begin{array}{l}\text { At least } \\
\text { a critical } \\
\text { inhaler } \\
\text { error* }\end{array}$} & \multirow{2}{*}{$\begin{array}{l}\% \text { difference } \\
\text { in health care } \\
\text { resource use } \\
\text { due to critical } \\
\text { inhaler errors }\end{array}$} & \multirow{2}{*}{$\begin{array}{l}\text { Absolute } \\
\text { difference in } \\
\text { health care } \\
\text { resource } \\
\text { use/I00 patients }\end{array}$} \\
\hline & Yes & $\overline{\text { No }}$ & & & Yes & $\overline{\text { No }}$ & & \\
\hline \multicolumn{9}{|l|}{ Hospital admissions, $\%$} \\
\hline Never & 55 & 62 & & & 76 & 86 & & \\
\hline I & 26 & 23 & 3 & 3 & 13 & 9 & 4 & 4 \\
\hline $2-3^{a}$ & 16 & II & 5 & 12.5 & 9 & 3 & 6 & 15 \\
\hline$>3^{b}$ & 3 & 4 & -1 & -4 & 2 & 2 & 0 & 0 \\
\hline $\begin{array}{l}\text { Total variation errors vs } \\
\text { no errors/ } 100 \text { patients }\end{array}$ & & & & 11.5 & & & & 19 \\
\hline \multicolumn{9}{|c|}{ Emergency department visits, \% } \\
\hline Never & 64 & 71 & & & 69 & 81 & & \\
\hline 1 & 24 & 22 & 2 & 2 & 16 & 11 & 5 & 5 \\
\hline $2-3^{a}$ & 10 & 4 & 6 & 15 & 10 & 3 & 7 & 17.5 \\
\hline$>3^{b}$ & 2 & 3 & -1 & -4 & 5 & 4 & I & 4 \\
\hline $\begin{array}{l}\text { Total variation errors vs } \\
\text { no errors/ } 100 \text { patients }\end{array}$ & & & & 13 & & & & 26.5 \\
\hline \multicolumn{9}{|l|}{ Antimicrobial courses, \% } \\
\hline Never & 20 & 30 & & & 34 & 41 & & \\
\hline 1 & 31 & 29 & 2 & 2 & 25 & 30 & -5 & -5 \\
\hline $2-3^{a}$ & 33 & 26 & 7 & 17.5 & 17 & 18 & -1 & -2.5 \\
\hline$>3^{b}$ & 15 & 15 & 0 & 0 & 14 & 11 & 3 & 12 \\
\hline $\begin{array}{l}\text { Total variation errors vs } \\
\text { no errors/ } 100 \text { patients }\end{array}$ & & & & 19.5 & & & & 4.5 \\
\hline Corticosteroid courses, & & & & & & & & \\
\hline Never & 29 & 37 & & & 27 & 35 & & \\
\hline 1 & 19 & 22 & -3 & -3 & 35 & 30 & 5 & 5 \\
\hline $2-3^{a}$ & 26 & 30 & -4 & -10 & 19 & 22 & -3 & -7.5 \\
\hline$>3^{b}$ & 26 & II & 15 & 60 & 19 & 13 & 6 & 24 \\
\hline $\begin{array}{l}\text { Total variation errors vs } \\
\text { no errors/ } 100 \text { patients }\end{array}$ & & & & 47 & & & & 21.5 \\
\hline
\end{tabular}

Notes: a Considered as 2.5 admissions/courses of treatment, bconsidered as 4 admissions/courses of treatment. *Reprinted from Respir Med, 20I I; $105(6)$, Melani AS, Bonavia $\mathrm{M}$, Cilenti $\mathrm{V}$, et al, Inhaler mishandling remains common in real life and is associated with reduced disease control, pages $930-938,{ }^{12}$ Copyright $@ 201 \mathrm{I}$, with permission from Elsevier.

Abbreviation: COPD, chronic obstructive pulmonary disease.

Table 2 Unitary costs of health care resources for base case analysis

\begin{tabular}{|c|c|c|c|c|}
\hline & \multicolumn{2}{|l|}{ COPD } & \multicolumn{2}{|l|}{ Asthma } \\
\hline & Unitary cost $(€)$ & Source & Unitary cost $(€)$ & Source \\
\hline $\begin{array}{l}\text { Hospital } \\
\text { admissions }\end{array}$ & $1,600.00$ & $\begin{array}{l}\text { DRG 88: chronic obstructive } \\
\text { pulmonary disease }{ }^{13}\end{array}$ & I,832.00 & $\begin{array}{l}\text { DRG 97: bronchitis and asthma age } \\
>17 \text { years without } \mathrm{cc}^{13}\end{array}$ \\
\hline $\begin{array}{l}\text { Emergency } \\
\text { department }\end{array}$ & 344.26 & Ministry of Health: Mattoni SSN & 344.26 & $\begin{array}{l}\text { Ministry of Health: Mattoni SSN Project: } \\
\text { Emergency Room and } 118 \text { System. }{ }^{14}\end{array}$ \\
\hline $\begin{array}{l}\text { visits } \\
\text { Antimicrobial } \\
\text { courses }^{\mathrm{a}}\end{array}$ & 13.04 & $\begin{array}{l}\text { System: }{ }^{14} \text { acute pulmonary condition } \\
\text { bPublic price per pack: levofloxacin: } \\
500 \mathrm{mg} / \text { day } 10 \text { days; pack } 5 \text { tabs } 500 \\
\mathrm{mg} € 6.25 \text { or ciprofloxacin: pack } 6 \text { tabs } \\
500 \mathrm{mg}, 500 \mathrm{mg} \text { BID } 7 \text { days } € 6.79\end{array}$ & 13.04 & $\begin{array}{l}\text { IRDRG 235380: acute pulmonary condition } \\
\text { 'Public price per pack: levofloxacin: } \\
500 \mathrm{mg} / \text { day } 10 \text { days; pack } 5 \text { tabs } 500 \mathrm{mg} \\
€ 6.25 \text { or ciprofloxacin: } 6 \text { tabs } 500 \mathrm{mg}, 500 \mathrm{mg} \\
\text { BID } 7 \text { days } € 6.79\end{array}$ \\
\hline $\begin{array}{l}\text { Corticosteroid } \\
\text { courses }^{\mathrm{a}}\end{array}$ & 6.68 & $\begin{array}{l}\text { bPublic price per pack: prednisone: } \\
\text { pack } 25 \mathrm{mg} 10 \text { tabs } € 5.10 \text { followed by } \\
\text { pack } 5 \mathrm{mg} 10 \text { tabs } € 1.58\end{array}$ & 5.34 & $\begin{array}{l}\text { 'Public price per pack: prednisone: } \\
\text { pack } 25 \mathrm{mg} 10 \text { tabs } € 5.10 \text { followed by pack } \\
5 \mathrm{mg} 10 \text { tabs } € I .58 \text { or methylprednisolone } \\
\text { pack } 40 \mathrm{mg} \text { I vial/day } € 4\end{array}$ \\
\hline
\end{tabular}

Note: ${ }^{\mathrm{a} F o r}$ drugs, average values of the most widely used drugs were used to estimate the cost per course of treatment. bltalian Medicines Agency. Tranparency List: All public prices for drugs, except for methylprednisolone. Rome: Italian Medicines Agency; 20I5. Available from: http://www.agenziafarmaco.gov.it/sites/default/files/Elenco farmaci_equivalenti_Principio_attivo_15.05.2015.pdf. Merhylprednisolone public price is available at Farmadati which is a database containing all the information about the medicines for human or veterinary use registered in Italy, equivalent medicines, homeopathic and parapharmaceutical products; available from: http://www.farmadati.it. Abbreviations: BID, twice a day; cc, comorbilities and complications; COPD, chronic obstructive pulmonary disease; DRG, Diagnosis Related Group; IRDRG, InternationalRefined Diagnosis Related Group. 
an excess of 19 hospitalizations, 26.5 ER visits, 4.5 antimicrobial courses, and 21.5 corticosteroids courses. These differences in resource consumption were associated with a yearly incremental health care cost for 100 patients, due to inhalation errors, of $€ 23,444$ in COPD patients and $€ 44,104$ in asthma patients (Table 3 ).

The most important health care cost differences between patients with and without critical inhaler errors are related to hospitalizations (accounting for about $78 \%$ of the total difference in both pathologies) and ER visits (accounting for about $20 \%$ of the total difference).

If the Italian real-world cost data for hospitalizations was considered (already reported), as sensitivity analysis, the incremental cost per 100 patients due to critical inhaler errors increased to $€ 50,871$ in COPD patients and to $€ 59,471$ in asthma patients, with hospitalizations and ER visits being the most significant cost drivers, accounting for almost the total expenditure difference.

\section{Discussion}

Inhaled therapies have always been central to the treatment of asthma and COPD, and the Global Initiative for Asthma guidelines consider the ability to deliver drugs directly to airways a major advantage of inhaled treatment. ${ }^{8}$

Inhaler errors represent a critical issue in the management of COPD and asthma patients, as they are associated with worsening in disease control, increased rate of exacerbation in COPD patients, increased health care resource consumption, and consequently, increased health care expenditure.

The importance of correct inhalation technique and the correlation between the switch of inhaler therapy, and a worsening in the pathology control, a deterioration in the quality of life of patients, and an increase in resource consumption are widely recognized. ${ }^{16-21}$
With patents expiring for some of the most widely used inhaled drugs, several analogs of branded inhaled corticosteroids/long-acting $\beta$-adrenoceptor agonists fixed-dose combinations are entering the market with different inhaler devices.

To improve inhaler techniques and reduce critical inhalation errors, adequate training is essential when a patient is switched from one device to another. ${ }^{18,22-29}$

A very recent study ${ }^{30}$ highlighted the possible issues related to nonconsented inhaler switches without adequate training in COPD patients and the relevance of the economic implications of inappropriate switching without performing a specific economic analysis.

The present analysis, which applies Italian health care costs to differences in resource consumption between patients with and without critical errors in the use of inhaler devices reported in a real-world study, highlights the relevance of health care cost increases related to errors in inhalation techniques. Costs ranged from approximately $€ 200$ to $€ 600$ / patient/year (which represented, even without taking into consideration the clinical consequences, a relevant part of the yearly cost of the most widely used inhaled drugs).

While it may appear to be a benign decision, changing or switching inhaler device can have a large effect on disease control. Because different devices require very different techniques for use, switching inhaler device (in particular, nonconsensual switches) may be associated with a poor inhalation technique unless patients are carefully counseled.

It is therefore crucial to consider all relevant costs, including those related to training sessions, additional consultations, repeated prescriptions, and management of acute events: these costs may contribute to reduce the potential benefit coming from switching inhalers. ${ }^{11}$

Table 3 Incremental yearly expenditure per 100 hypothetic patients with vs without critical inhaler errors

\begin{tabular}{|c|c|c|c|c|c|c|}
\hline & \multicolumn{3}{|l|}{ COPD } & \multicolumn{3}{|l|}{ Asthma } \\
\hline & $\begin{array}{l}\text { Yearly absolute difference } \\
\text { in health care resource } \\
\text { use for } 100 \text { patients with } \\
\text { vs without errors }\end{array}$ & $\begin{array}{l}\text { Unitary } \\
\text { cost }(€)\end{array}$ & $\begin{array}{l}\text { Yearly difference } \\
\text { in health care } \\
\text { cost for } 100 \\
\text { patients }(€)\end{array}$ & $\begin{array}{l}\text { Yearly absolute difference } \\
\text { in health care resource } \\
\text { use for } 100 \text { patients with } \\
\text { vs without errors }\end{array}$ & $\begin{array}{l}\text { Unitary } \\
\text { cost }(€)\end{array}$ & $\begin{array}{l}\text { Yearly difference } \\
\text { in health care } \\
\text { cost for } 100 \\
\text { patients }(€)\end{array}$ \\
\hline Hospital admissions & 11.5 & $1,600.00$ & $18,400.00$ & 19 & $1,832.00$ & $34,808.00$ \\
\hline $\begin{array}{l}\text { Emergency department } \\
\text { visits }\end{array}$ & 13 & 344.26 & $4,475.38$ & 26.5 & 344.26 & $9,122.89$ \\
\hline Antimicrobic courses & 19.5 & 13.04 & 254.28 & 4.5 & 13.04 & 58.68 \\
\hline Corticosteroid courses & 47 & 6.68 & 313.96 & 21.5 & 5.34 & || $4.8 \mid$ \\
\hline Total health care costs & & & $23,443.62$ & & & $44,104.38$ \\
\hline Difference/patient/year & & & 234.44 & & & 441.04 \\
\hline
\end{tabular}

Abbreviation: COPD, chronic obstructive pulmonary disease. 
These economic considerations, associated with previously reported clinical issues related to the untrained switch of inhaler devices, emphasize the importance of carefully considering switching, with particular regard to those patients who are familiar and stabilized on one type of inhaler. ${ }^{11}$

\section{Author contributions}

All authors contributed toward data analysis, drafting and critically revising the paper and agree to be accountable for all aspects of the work.

\section{Disclosure}

AR and DPR are consultants for AstraZeneca. CM is a consultant for AstraZeneca and GlaxoSmithKline. This study was funded by an unrestricted grant from AstraZeneca, Italy. The authors report no other conflicts of interest in the work.

\section{References}

1. Global Burden of Disease Study 2013 Collaborators. Global, regional, and national incidence, prevalence, and years lived with disability for 301 acute and chronic diseases and injuries in 188 countries, 1990-2013: a systematic analysis for the Global Burden of Disease Study 2013. Lancet. 2015;386(9995):743-800.

2. Masoli M, Fabian D, Holt S, Beasley R. The global burden of asthma: executive summary of the GINA Dissemination Committee Report. Allergy. 2004;59(5):469-478.

3. Eagan TM, Brøgger JC, Eide GE, Bakke PS. The incidence of adult asthma: a review. Int J Tuberc Lung Dis. 2005;9(6):603-612.

4. Mathers CD, Loncar D. Projections of global mortality and burden of disease from 2002 to 2030. PLoS Med. 2006;3(11):e442.

5. Blasi F, Cesana G, Conti S, et al. The clinical and economic impact of exacerbations of chronic obstructive pulmonary disease: a cohort of hospitalized patients. PLoS One. 2014;9(6):e101228.

6. Accordini S, Corsico AG, Braggion M, et al. The cost of persistent asthma in Europe: an international population-based study in adults. Int Arch Allergy Immunol. 2013;160(1):93-101.

7. Braido F, Baiardini I, Sumberesi M, Blasi F, Canonica GW. Obstructive lung diseases and inhaler treatment: results from a national public pragmatic survey. Respir Res. 2013;14:94.

8. Global Initiative For Asthma. Pocket guide for asthma management and prevention (for adults and children older than 5 years). A pocket guide for physicians and nurses. Updated 2015. Based on the global strategy for asthma management and prevention. Available from: http://www. ginasthma.org/local/uploads/files/GINA_Pocket_2015.pdf. Accessed December 1, 2015.

9. Global Initiative for Chronic Obstructive Lung Disease. Global strategy for the diagnosis, management, and prevention of chronic obstructive pulmonary disease. Updated 2015. Available from: http://www.goldcopd.org/uploads/users/files/GOLD_Report_2015_Sept2.pdf. Accessed December 1, 2015.

10. European Medicines Agency Committee for Medicinal Products for Human Use (CHMP). Guideline on the Requirements for Clinical Documentation for Orally Inhaled Products (OIP) Including the Requirements for Demonstration of Therapeutic Equivalence between Two Inhaled Products for Use in the Treatment of Asthma and Chronic Obstructive Pulmonary Disease. London, UK: European Medicines Agency; 2009. Available from: http://www.ema.europa.eu/docs/en_GB/document_library/ Other/2010/09/WC500096775.pdf. Accessed December 1, 2015.
11. Lavorini F, Braido F, Baiardini I, Blasi F, Canonica GW. Asthma and COPD: interchangeable use of inhalers. A document of Italian Society of Allergy, Asthma and Clinical Immmunology (SIAAIC) \& Italian Society of Respiratory Medicine (SIMeR). Pulm Pharmacol Ther. 2015;34:25-30.

12. Melani AS, Bonavia M, Cilenti V, et al. Inhaler mishandling remains common in real life and is associated with reduced disease control. Respir Med. 2011;105(6):930-938.

13. DECRETO 18 ottobre 2012. Remunerazione prestazioni di assistenza ospedaliera per acuti, assistenza ospedaliera di riabilitazione e di lungodegenza post acuzie e di assistenza specialistica ambulatoriale. (13A00528) (GU Serie Generale n.23 del 28-1-2013 - Suppl. Ordinario n. 8. [Decree 18 October 2012. Remuneration performance of hospital assistance for acute, hospital assistance to rehabilitation and long-term assistance after acute and specialist outpatient assistance]. Available from: http://www.gazzettaufficiale.it/eli/id/2013/01/28/13A00528/sg. Accessed December 1, 2015. Italian.

14. Mattoni SSN: Costo medio standardizzato per codice triage per struttura per l' anno 2003; Ministero della Salute, Progetto Mattoni SSN: Pronto Soccorso e sistema 118. [Mattoni SSN: Average standardized cost for emergency room access for year 2003. Ministry of Health: Mattoni SSN Project: Emergency Room and 118 System]. Available from: http://www.mattoni. salute.gov.it/mattoni/documenti/11_Valutazione_costi_dell_emergenza. pdf. Accessed December 1, 2015. Italian.

15. Dal Negro RW, Micheletto C, Tosatto R, Dionisi M, Turco P, Donner CF. Costs of asthma in Italy: results of the SIRIO (Social Impact of Respiratory Integrated Outcomes) study. Respir Med. 2007;101: 2511-2519.

16. Lavorini F, Fontana GA, Usmani OS. New inhaler devices - the good, the bad and the ugly. Respiration. 2014;88(1):3-15.

17. Bjermer L. The importance of continuity in inhaler device choice for asthma and chronic obstructive pulmonary disease. Respiration. 2014; 88(4):346-352.

18. Giraud V, Roche N. Misuse of corticosteroid metered-dose inhaler is associated with decreased asthma stability. Eur Respir J. 2002;19: 246-251.

19. Gustafsson P, Taylor A, Zanen P, Chrystyn H. Can patients use all dry powder inhalers equally well? Int J Clin Pract Suppl. 2005;(149): $13-18$.

20. Price D, Summers M, Zanen P. Could interchangeable use of dry powder inhalers affect patients? Int J Clin Pract Suppl. 2005;(149):3-6.

21. Price D. Do healthcare professionals think that dry powder inhalers can be used interchangeably? Int J Clin Pract Suppl. 2005;(149):26-29.

22. Lavorini F, Magnan A, Dubus JC, et al. Effect of incorrect use of dry powder inhalers on management of patients with asthma and COPD. Respir Med. 2008;102:593-604.

23. Takemura M, Kobayashi M, Kimura K, et al. Repeated instruction on inhalation technique improves adherence to the therapeutic regimen in asthma. J Asthma. 2010;47:202-208.

24. Fink JB, Rubin BK. Problems with inhaler use: a call for improved clinician and patient education. Respir Care. 2005;50:1360-1374; discussion 1374-1375.

25. Chrystyn H. Do patients show the same level of adherence with all dry powder inhalers? Int J Clin Pract Suppl. 2005;(149):19-25.

26. Doyle S, Lloyd A, Williams A, et al. What happens to patients who have their asthma device switched without their consent? Prim Care Respir J. 2010;19:131-139.

27. Lindgren $S, B a k e B$, Larsson S. Clinical consequences of inadequate inhalation technique in asthma therapy. Eur J Respir Dis. 1987;70(2):93e8.

28. Thomas M, Price D, Chrystyn H, Lloyd A, Williams AE, von Ziegenweidt J. Inhaled corticosteroids for asthma: impact of practice level device switching on asthma control. BMC Pulm Med. 2009;9:1.

29. Scichilone N. Asthma control: the right inhaler for the right patient. Adv Ther. 2015;32:285-292.

30. Braido F, Lavorini F, Blasi F, Baiardini I, Canonica GW. Switching treatments in COPD: implications for costs and treatment adherence. Int J Chron Obstruct Pulmon Dis. 2015;10:2601-2608. 


\section{Publish your work in this journal}

The International Journal of COPD is an international, peer-reviewed journal of therapeutics and pharmacology focusing on concise rapid reporting of clinical studies and reviews in COPD. Special focus is given to the pathophysiological processes underlying the disease, intervention programs, patient focused education, and self management protocols.

This journal is indexed on PubMed Central, MedLine and CAS. The manuscript management system is completely online and includes a very quick and fair peer-review system, which is all easy to use. Visit http://www.dovepress.com/testimonials.php to read real quotes from published authors.

Submit your manuscript here: http://www.dovepress.com/international-journal-of-chronic-obstructive-pulmonary-disease-journal 